\title{
GELIAT PROVINSI KALIMANTAN TIMUR PASCA PEMEKARAN DAERAH
}

\section{(EAST KALIMANTAN PROVINCE STRETCHING POST REGIONAL EXPANSION)}

\author{
Diana Pujianty*, Puji Wibowo** \\ *STIE DR Mochtar Thalib \\ Jalan Pinang No.67 - Setu Raya, Cipayung,, RT.3/RW.4, Cipayung, Jakarta Timur 13840 \\ dianapujianty47@gmail.com \\ ** Politeknik Keuangan Negara STAN \\ Jalan Bintaro Utama Sektor V, Bintaro Jaya, Tangerang Selatan 15222
}

Diterima: 29 Januari 2019; Direvisi: 28 Mei 2019; Disetujui: 31 Mei 2019

\begin{abstract}
ABSTRAK
Kalimantan Timur terkenal sebagai daerah yang kaya akan sumber daya alam, khususnya yang terkait dengan kehutanan, pertambangan, perikanan dan minyak dan gas. Sejak 2012, provinsi ini telah dibagi menjadi dua wilayah, Kalimantan Timur dengan 10 kabupaten / kota dan provinsi baru, Kalimantan Utara telah mengelola 5 kabupaten/kota. Kinerja Anggaran Daerah (APBD) telah dipengaruhi oleh kebijakan ini. Penelitian ini bertujuan untuk memberikan analisis perbandingan mengingat kinerja anggaran daerah dan daerah sebelum dan sesudah ekspansi Kalimantan Timur. Hasil penelitian menunjukkan bahwa ditinjau dari perspektif APBD provinsi, terdapat perbedaan statistik antara periode sebelum dan sesudah pemekaran provinsi. Perbedaan tersebut terutama ditemukan dalam dengan rasio desentralisasi, rasio interdependensi, rasio belanja modal, dan rasio pengeluaran tak terduga. Keempat jenis rasio tersebut menunjukkan performa yang semakin baik pada masa sesudah pemekaran daerah. Studi ini juga menunjukkan hasil bahwa ditinjau dari perspektif APBD kabupaten/kota yang berada dalam wilayah administrasi Provinsi Kalimantan Timur, tidak terdapat perbedaan kinerja APBD yang signifikan secara statistik antara periode sebelum dan sesudah pemekaran.
\end{abstract}

Kata kunci: kinerja APBD, pemekaran daerah, rasio keuangan.

\begin{abstract}
East Kalimantan is well-known as a natural resources-rich region, particularly associated with forestry, mining, fishery and oil and gas. Since 2012, this province has been splited into two regions, East Kalimantan with 10 regencies/municipalities and the new province, North Kalimantan has administered 5 cities. Regional Budget (APBD) performances have been affected by this policy. This research aims to provide comparison analysis in the light of regional and local budget performance before and after East Kalimantan expansion. It is confirmed that from budget province perspective, there were statistically differences between pre-expansion and postexpansion periods. Those differences were associated with decentralization ratio, interdependency ratio, capital expenditure ratio, and unexpected expenditure ratio in East Kalimantan budget. Meanwhile, it has been discovered that there were no statistically differences between preexpansion era and post-expansion era in terms of budget performances in East Kalimantan's regencies/municipalities.
\end{abstract}

Keywords: APBD Performance, regional expansion, financial ratio.

\section{PENDAHULUAN}

Indonesia hanya memiliki 8 (delapan) provinsi pada awal masa kemerdekaan. Jumlah provinsi tersebut terus mengalami perkembangan. Pemekaran provinsi pertama kali terjadi 
pada tahun 1950 dimana Provinsi Sumatera dimekarkan menjadi Sumatera Utara, Sumatera Tengah dan Sumatera Selatan. Pemekaran provinsi terbaru terjadi pada tahun 2012 dimana Provinsi Kalimantan Timur dimekarkan menjadi Provinsi Kalimantan Utara dan Provinsi Kalimantan Timur dengan berlandaskan Undang-Undang Nomor 20 Tahun 2012.

Pemekaran daerah di Indonesia dilandasi oleh Undang-Undang Nomor 23 Tahun 2014 tentang Pemerintahan Daerah. Pemekaran daerah sebagaimana dimaksud dalam pasal 33 ayat (1) butir a berupa pemecahan daerah provinsi atau daerah kabupaten/kota untuk menjadi dua atau lebih daerah baru. Berdasarkan pasal 31 ayat (2) Undang-undang Nomor 23 Tahun 2014, adanya penataan daerah ditujukan untuk (i) mewujudkan efektivitas penyelenggaraan pemerintahan daerah, (ii) mempercepat peningkatan kesejahteraan masyarakat, (iii) mempercepat peningkatan kualitas pelayanan publik, (iv) meningkatkan kualitas tata kelola pemerintahan, (v) meningkatkan daya saing nasional dan daya saing daerah, dan (vi) memelihara keunikan adat istiadat, tradisi, dan budaya daerah. Cita-cita luhur kebijakan pemekaran daerah tentu saja perlu didukung antara lain kemampuan fiskal daerah yang tercermin dari kinerja Anggaran Pendapatan dan Belanja Daerah (APBD).

Provinsi Kalimantan Timur memiliki 14 kota/kabupaten sebelum dimekarkan menjadi dua provinsi. Pemekaran daerah tersebut membuat Provinsi Kalimantan Timur kini hanya memiliki 9 kota/kabupaten dimana 5 kota/kabupaten bergabung ke dalam Provinsi Kalimantan Utara. Namun pada tahun 2013 wilayah Kabupaten Kutai Barat yang termasuk dalam Provinsi Kalimantan Timur dimekarkan menjadi Kabupaten Kutai Barat dan Kabupaten Mahakam Ulu, sehingga Provinsi Kalimantan Timur kini memiliki 10 kota/kabupaten.

Pemerintah daerah memiliki rencana kerja tahunan beserta keuangannya yang tercermin dari potret APBD. Dokumen APBD tersebut merupakan dasar pengelolaan keuangan daerah dalam masa 1 (satu) tahun anggaran sesuai dengan undang-undang mengenai keuangan negara. APBD meliputi pendapatan daerah, belanja daerah dan pembiayaan daerah. APBD idealnya disusun untuk mengakomodir preferensi masyarakat mengenai jenis pelayanan publik yang paling diminati. Terlebih, di era otonomi daerah dan desentralisasi fiskal, para kepala daerah dituntut untuk mendengarkan langsung tuntutan dan keinginan rakyatnya. Dalam fiscal mobility theory sebagaimana diutarakan oleh Bahl dan Linn (1992) menggambarkan tingkat mobilitas penduduk antardaerah yang dipicu oleh tingkat kesejahteraan masyarakat yang lebih tinggi. Perbaikan kualitas hidup orang akan mendorong mereka untuk memilih daerah yang menyediakan pelayanan publik yang lebih baik. Daerah diminta untuk berpacu meningkatkan kualitas hidup masyarakatnya demi menyesuaikan mobilitas atas suatu pelayanan publik yang lebih menarik.

Oates (1972) juga berpendapat bahwa pendelegasian fiskal kepada pemerintah yang berada di level bawah diharapkan dapat memberikan peningkatan ekonomi mengingat pemerintah daerah memiliki kedekatan dengan masyarakatnya dan mempunyai keunggulan informasi dibandingkan dengan pemerintah pusat. Oleh karena itu, pemerintah daerah seyogianya dapat memberikan pelayanan publik yang benar-benar dibutuhkan di daerahnya. Senada dengan hal tersebut, Davoodi dan Zou (1998) sebagaimana dikutip oleh Wibowo (2008) berpendapat bahwa munculnya 'kompetisi' atau persaingan antardaerah akan meningkatkan kesamaan pandangan antara apa yang diharapkan oleh masyarakat dengan suatu program yang dijalankan oleh pemerintahnya.

Pemekaran daerah pada prinsipnya bertujuan untuk membuat kinerja pembangunan yang lebih mapan. Santika, et al (2018) mengungkapkan bahwa pemekaran daerah merupakan solusi terbaik untuk pemerataan pembangunan daerah dengan mengutamakan kesejahteraan masyarakat. Hal ini diungkapkan dalam penelitiannya atas pemerataan ekonomi di Kabupaten Lombok Utara. 
Namun demikian, penelitian yang membahas mengenai dampak pemekaran daerah terhadap kinerja APBD belum menemukan simpulan yang seragam. Sebagian peneliti mengungkapkan dampak positif pemekaran terhadap pembangunan maupun kinerja APBD. Penelitian yang mendukung hal tersebut antara lain penelitian atas dampak pemekaran daerah Kabupaten Kepulauan Meranti dari Kabupaten Bengkalis. Dalam penelitian Hamidi dan Tampubolon (2017) tersebut disimpulkan bahwa untuk kabupaten induk pascapemekaran, tingkat pelayanan publik pasca pemekaran wilayah cenderung stabil. Optimalnya pelayanan publik di daerah pemekaran disebabkan tersedianya tenaga layanan publik dan efektifnya pemanfaatan pelayanan publik. Oleh karena itu, dampak pemekaran daerah terhadap penyediaan pelayanan publik dinilai baik bagi daerah baru maupun kabupaten induknya.

Azhar (2008) berpendapat bahwa terdapat perbedaan kinerja keuangan pemerintah kabupaten/kota dalam bentuk desentralisasi fiskal pada era sebelum dan setelah diberlakukannya otonomi daerah. Hal ini didasari pada bukti empiris dalam riset terkait pemerintah daerah kabupaten/kota di Nangroe Aceh Darussalam dan Sumatera Utara. Adapun Sucandrawati (2016) menemukan bahwa terdapat perbedaan yang signifikan dalam hal rasio belanja operasi terhadap total belanja pada APBD kabupaten antara sebelum dan setelah pemekaran wilayah pada Provinsi Lampung. Endaryanto, et al. (2018) juga menemukan bahwa kinerja ekonomi dan keuangan daerah pemekaran relatif membaik. Hal ini dibuktikan pada kasus kabupaten pemekaran Pringsewu, Mesuji dan Tulang Bawang Barat yang menunjukkan hasil lebih tinggi dibandingkan kabupaten induk (Tanggamus dan Tulang Bawang). Indikator kinerja keuangan kabupaten pemekaran yang tinggi dibandingkan kabupaten induk didorong oleh turunnya indikator ketergantungan fiskal, penciptaan pendapatan, proporsi belanja modal, dan kontribusi sektor pemerintah

Dampak positif pemekaran daerah ternyata tidak selalu terwujud di beberapa daerah. Penelitian secara makro mengenai performa APBD telah dibahas oleh Nugroho (2016:113). Dalam risetnya diungkapkan bahwa tingkat kemandirian daerah dalam pengelolaan keuangan masih rendah. Hal ini dijelaskannya dalam penelitiannya mengenai analisis atas kemandirian pemda dalam mengelola keuangannya untuk kab/kota diseluruh Indonesia periode 2006 2014. Dalam penelitian yang lain, Mengkuningtyas (2008) menyimpulkan bahwa tidak terdapat perbedaan yang signifikan pada kinerja keuangan kabupaten antara sebelum dan setelah pemekaran wilayah. Hal senada juga terjadi untuk pemekaran daerah di kabupaten/kota di Provinsi Sumatera Selatan (Mulatsih 2014).

Dari beberapa penelitian di atas, dapat disimpulkan bahwa potret kinerja keuangan daerah baik sebelum maupun setelah pemekaran daerah belum menunjukkan keseragaman pola. Hal ini terbukti dari belum adanya konsistensi hasil penelitian antardaerah dan antarwaktu. Perbedaan hasil riset tersebut menunjukkan bahwa masih terdapat peluang untuk meneliti kembali persoalan kinerja keuangan daerah setelah adanya pemekaran dengan mengambil objek maupun rasio keuangan yang lain.

Objek penelitian kali ini berupa pemerintah provinsi dan pemerintah kabupaten/kota dalam provinsi yang sama (incumbent region), yaitu Provinsi Kalimantan Timur. Sementara indikator kinerja keuangan diperluas dengan menggabungkan indikator-indikator kinerja pada penelitian sebelumnya dan menambahkan indikator lain yaitu rasio ketergantungan keuangan daerah, rasio belanja tidak terduga terhadap total belanja dan rasio efisiensi belanja daerah. Ketiga rasio tersebut penting digunakan dalam penelitian ini mengingat persoalan klasik yang kerap kali muncul dalam kebijakan pemekaran adalah terkait otonomi daerah dan kapasitas pengelolaan APBD.

Berdasarkan pembahasan di atas, perumusan masalah dalam riset ini adalah apakah terdapat perbedaan kinerja APBD pada Provinsi Kalimantan Timur antara sebelum dan sesudah pemekaran daerah? 


\section{METODE}

Penelitian ini merupakan penelitian kuantitatif deskriptif dengan menggunakan data sekunder berupa realisasi APBD yang diperoleh dari laman resmi pemerintahan Provinsi KalimantanTimur, Kementerian Dalam Negeri, Direktorat Jendral Perimbangan Keuangan dan Badan Pusat Statistik.

Pengumpulan data pada penelitian ini melalui literatur review dan observasi non perilaku (nonbehavioral observation). Jenis observasi non perilaku yang digunakan adalah analisis catatan. Analisis catatan dapat berupa pengumpulan data, dimana data tersebut adalah data sekarang atau catatan data historis (Sugiyono 2015).

Kinerja APBD yang diamati dalam penelitian ini adalah realisasi APBD Provinsi Kalimantan Timur dan APBD kabupaten/kota yang ada di Provinsi Kalimantan Timur selama periode tahun 2008-2015. Daerah tingkat II yang berada di wilayah administrasi Provinsi Kalimantan Timur adalah Kabupaten Berau, Kabupaten Kutai Barat, Kabupaten Kutai Kartanegara, Kabupaten Kutai Timur, Kabupaten Paser, Kabupaten Penajam Paser Utara, Kota Samarinda, Kota Bontang, Kota Balikpapan, dan Kabupaten Mahakam Ulu.

Penelitian ini menggunakan analisis rasio keuangan dimana rasio-rasio keuangan tersebut akan diuji dengan menggunakan uji normalitas dan uji beda. Uji normalitas dilakukan untuk mengetahui apakah suatu data berdistribusi normal atau tidak. Uji beda dilakukan untuk mengetahui ada tidaknya perbedaan yang signifikan secara statistik untuk menerima atau menolak hipotesis awal (Ho).

Rasio-rasio keuangan yang digunakan dalam riset ini adalah rasio derajat desentralisasi, rasio ketergantungan keuangan daerah, rasio kemandirian keuangan daerah, rasio efektivitas pendapatan asli daerah, rasio efisiensi dan rasio keserasian belanja. Pemilihan rasio ini dilakukan dengan pertimbangan bahwa rasio dimaksud dapat dianggap sebagai proxy dalam mengukur performa APBD guna mendukung tujuan dilakukannya pemekaran daerah. Disamping itu, beberapa rasio merupakan ukuran kinerja yang belum digunakan pada penelitian sebelumnya sehingga pengembangan rasio ini merupakan keterbaruan di dalam penelitian kami. Perbandingan rasio dihitung dengan menggunakan komparasi angka rata-rata tahun 2008 s.d. 2011 (untuk periode sebelum pemekaran) dan tahun 2012 s.d. 2015 (untuk periode setelah pemekaran).

Untuk melakukan penilaian kinerja APBD, penelitian ini menggunakan beberapa rasio keuangan sebagai proxy berupa rasio derajat desentralisasi, ketergantungan keuangan daerah, kemandirian daerah, efektivitas Pendapatan Asli Daerah (PAD), efisiensi, dan rasio-rasio berkaitan dengan pengelolaan belanja. Rasio derajat desentralisasi digunakan untuk menunjukkan derajat kontribusi PAD terhadap total penerimaan daerah. Semakin tinggi kontribusi PAD maka semakin tinggi kemampuan pemerintah daerah dalam penyelenggaraan desentralisasi. Adapun rumus untuk mencari derajat desentralisasi menurut Mahmudi (2016:140) adalah sebagai berikut:

Derajat Desentralisasi $=($ Pendapatan Asli Daerah $) /($ Total Pendapatan Daerah $) \times 100 \%$

Rasio ketergantungan keuangan daerah merupakan indikator yang menunjukkan seberapa besar dana transfer dari pemerintah pusat yang diperoleh pemerintah daerah. Semakin tinggi nilai rasio ketergantungan keuangan daerah maka semakin besar tingkat ketergantungan pemerintah daerah terhadap pemerintah pusat dan/atau pemerintah provinsi. Adapun rumus untuk menghitung rasio ketergantungan keuangan daerah (Mahmudi 2016:140) adalah sebagai berikut: 
Derajat Ketergantungan Daerah $=($ Pendapatan Transfer $) /($ Total Pendapatan Daerah $) \times 100 \%$

Rasio kemandirian keuangan daerah digunakan untuk mengukur kemampuan pemerintah daerah dalam membiayai penyelenggaraan pemerintahan sendiri dengan membandingkan pendapatan asli daerah (PAD) dengan subsidi pemerintah pusat dan provinsi serta pinjaman daerah. Semakin tinggi nilai rasio kemandirian keuangan daerah menunjukkan semakin tinggi kemandirian keuangan pemerintah daerah. Adapun rumus untuk menghitung rasio kemandirian (Mahmudi 2016:140), yaitu:

Rasio Kemandirian $=($ Pendapatan Asli Daerah $) /($ Transfer Pusat + Provinsi + Pinjaman $) \times 100 \%$

Rasio efektivitas pendapatan asli daerah digunakan untuk menunjukkan kemampuan pemerintah daerah dalam memobilisasi penerimaan PAD sesuai dengan yang ditargetkan. Adapun rumus untuk mencari rasio efektivitas PAD (Mahmudi 2016:140) adalah sebagai berikut:

Rasio Efektivitas PAD = (Realisasi Penerimaan PAD $) /($ Target Penerimaan PAD $) \times 100 \%$

Realisasi PAD terhadap target penerimaan sebesar 100 persen atau pun di atasnya, masing-masing dikategorikan sebagai efektif dan sangat efektif. Pencapaian PAD dengan interval 90-99 persen diklasifikasikan sebagai cukup efektif. Adapun pencapaian PAD dalam interval 75-89 persen digolongkan kurang efektif dan di bawah 75 persen dikatakan tidak efektif.

Rasio efisiensi adalah rasio yang menggambarkan perbandingan antara output dan input atas realisasi pengeluaran dengan realisasi penerimaan daerah. Semakin kecil rasio ini, maka semakin efisien, begitu pula sebaliknya. Adapun rumus untuk mencari rasio efisiensi pendapatan daerah (Mahmudi 2016:140) adalah:

Rasio Efisiensi $=($ Realisasi Pengeluaran $) /($ Realisasi Penerimaan $)$

Adapun rasio-rasio pengelolaan belanja pada prinsipnya merupakan ukuran perbandingan antara jenis belanja tertentu dengan keseluruhan total belanja pemda. Rasio yang digunakan meliputi rasio belanja operasi, belanja modal, belanja tak terduga, yang masing-masing dibandingkan dengan total belanja APBD. Adapun rasio efisiensi belanja merupakan perbandingan realisasi belanja dibandingkan dengan pagu anggaran belanja dalam APBD

Berdasarkan uraian di atas, hipotesis dalam penelitian ini dirumuskan untuk mencapai tujuan penelitian yaitu mengetahui ada tidaknya perbedaan kinerja APBD antara sebelum dan sesudah pemekaran daerah. Menurut Sugiyono (2015:84), hipotesis diartikan sebagai jawaban sementara terhadap rumusan masalah penelitian. Kinerja APBD yang diamati meliputi APBD Provinsi Kalimantan Timur dan kabupaten/kota yang berada di wilayahnya. Oleh karena itu, dua hipotesis utama yang digunakan dalam riset kami meliputi:

a. Ho1: Tidak terdapat perbedaan kinerja APBD pada provinsi Kalimantan Timur antara sebelum dan sesudah pemekaran daerah.

b. Ho2: Tidak terdapat perbedaan kinerja APBD kabupaten/kota yang terdapat pada provinsi Kalimantan Timur antara sebelum dan sesudah pemekaran daerah. 


\section{HASIL DAN PEMBAHASAN}

Rata-rata rasio keuangan pemerintah Provinsi Kalimantan Timur secara umum mengalami peningkatan sejak pemekaran. Peningkatan tersebut antara lain terlihat dari derajat desentralisasi, rasio kemandirian keuangan daerah, rasio efisiensi, dan rasio belanja tidak terduga. Meningkatnya derajat desentralisasi dan rasio kemandirian keuangan daerah Pemerintah Provinsi Kalimantan Timur mengindikasikan terwujudnya peningkatan kemampuan Pemerintah Provinsi Kalimantan Timur dalam membiayai penyelenggaraan pemerintahannya sendiri terutama setelah adanya pemekaran daerah (Tabel 1). Sejalan dengan hal tersebut, rasio ketergantungan keuangan daerah semakin membaik yang ditunjukkan dengan menurunnya rasio Pendapatan transfer terhadap total Pendapatan daerah tersebut. Adapun tingkat efektivitas PAD, rasio belanja operasi, belanja modal justru mengalami penurunan. Tingkat efektivitas PAD yang semula 148 persen turun menjadi 115 persen memiliki makna ganda. Pertama, dari sisi perencanaan, menurunnya tingkat efektivitas PAD mengindikasikan kian membaiknya perencanaan Pendapatan daerah karena deviasi antara realisasi dan target PAD mengecil. Kedua, tingkat efektivitas yang menurun juga mengindikasikan potensi PAD sudah banyak yang direalisasikan oleh Pemerintah Provinsi Kalimantan Timur.

Tabel 1 Rata-rata Rasio Keuangan Pemerintah Provinsi Kalimantan Timur

\begin{tabular}{lcc}
\hline \multicolumn{1}{c}{ Rasio Keuangan } & Sebelum Pemekaran & Setelah Pemekaran \\
\hline Derajat Desentralisasi & $40 \%$ & $52 \%$ \\
Ketergantungan Keuangan Daerah & $60 \%$ & $46 \%$ \\
Kemandirian Keuangan Daerah & $67 \%$ & $115 \%$ \\
Efektivitas PAD & $148 \%$ & $113 \%$ \\
Efisiensi & $97 \%$ & $105 \%$ \\
Belanja Operasi & $58 \%$ & $57 \%$ \\
Belanja Modal & $26 \%$ & $22 \%$ \\
Belanja Tidak Terduga & $15 \%$ & $21 \%$ \\
Efisiensi Belanja Daerah & $105 \%$ & $101 \%$ \\
\hline
\end{tabular}

Sumber: Data riset yang diolah (2008 s.d. 2015)

Rata-rata rasio keuangan seluruh pemerintah kabupaten/kota di Provinsi Kalimantan Timur juga menunjukkan fenomena yang beragam. Serupa dengan APBD tingkat provinsi, derajat desentralisasi dan kemandirian keuangan daerah untuk APBD kabupaten/kota mengalami peningkatan meski relatif tidak signifikan, yakni masing-masing naik 2 dan 3 persen. Tingkat efektivitas PAD justru mengalami kenaikan 10 persen dari 122 persen menjadi 132 persen. Hal ini berarti, potensi PAD di tingkat kabupaten/kota masih banyak yang belum dioptimalkan. Rasio efisiensi juga mengalami kenaikan dari 96 persen menjadi 102 persen selama periode pengamatan. Meningkatnya rasio efisiensi justru diikuti dengan meningkatnya rasio efisiensi belanja daerah dari 83 persen menjadi 92 persen. Artinya, penghematan anggaran justru mengecil karena realisasi anggaran meningkat. Ikhtisar performa APBD kabupaten/kota dapat kita lihat pada Tabel 2.

Uji normalitas dilakukan terlebih dahulu sebelum melakukan pengujian apakah rasiorasio keuangan tersebut di atas menunjukkan adanya perbedaan secara statistik. Uji normalitas dilakukan untuk mengetahui apakah suatu data berdistribusi normal atau tidak. Suatu data dikatakan memiliki distribusi normal jika tingkat signifikansinya lebih besar dari 0,05. Uji normalitas yang digunakan dalam penelitian adalah uji Kolmogorov Smirnov seperti pada Tabel 3. 
Geliat Provinsi Kalimantan Timur Pasca Pemekaran Daerah

Diana Pujianty dan Puji Wibowo

Tabel 2 Rata-Rata Rasio Keuangan Seluruh Pemerintah Kab/Kota di Provinsi Kalimantan Timur

\begin{tabular}{lcc}
\hline \multicolumn{1}{c}{ Rasio Keuangan } & Sebelum Pemekaran & Setelah Pemekaran \\
\hline Derajat Desentralisasi & $6 \%$ & $8 \%$ \\
Ketergantungan Keuangan Daerah & $87 \%$ & $80 \%$ \\
Kemandirian Keuangan Daerah & $7 \%$ & $10 \%$ \\
Efektivitas PAD & $122 \%$ & $132 \%$ \\
Efisiensi & $96 \%$ & $102 \%$ \\
Belanja Operasi & $60 \%$ & $58 \%$ \\
Belanja Modal & $40 \%$ & $42 \%$ \\
Belanja Tidak Terduga & $1 \%$ & $0 \%$ \\
Efisiensi Belanja Daerah & $83 \%$ & $92 \%$ \\
\hline
\end{tabular}

Sumber: Data riset yang diolah (2008 s.d. 2015)

Tabel 3 Uji Normalitas Rasio Keuangan Pemerintah Provinsi Kalimantan Timur

\begin{tabular}{|c|c|c|c|c|}
\hline \multirow[t]{2}{*}{ Rasio } & \multicolumn{2}{|c|}{ Sebelum Pemekaran } & \multicolumn{2}{|c|}{ Setelah Pemekaran } \\
\hline & Kol. - Smirnov & $\begin{array}{c}\text { Sig. } \\
\text { (2-tailed) }\end{array}$ & Kol. - Smirnov & $\begin{array}{c}\text { Sig. } \\
\text { (2-tailed) }\end{array}$ \\
\hline Derajat Desentralisasi & 0,34 & 1,00 & 0,47 & 0,98 \\
\hline $\begin{array}{l}\text { Ketergantungan Keuangan } \\
\text { Daerah }\end{array}$ & 0,34 & 1,00 & 0,70 & 0,71 \\
\hline Kemandirian Keuangan Daerah & 0,35 & 1,00 & 0,63 & 0,83 \\
\hline Efektivitas PAD & 0,51 & 0,96 & 0,61 & 0,85 \\
\hline Efisiensi & 0,57 & 0,90 & 0,40 & 1,00 \\
\hline Belanja Operasi/Total Belanja & 0,38 & 1,00 & 0,43 & 0,99 \\
\hline Belanja Modal/Total Belanja & 0,44 & 0,99 & 0,52 & 0,95 \\
\hline $\begin{array}{l}\text { Belanja Tak Terduga/Total } \\
\text { Belanja }\end{array}$ & 0,52 & 0,95 & 0,47 & 0,98 \\
\hline Efisiensi Belanja Daerah & 0,44 & 0,99 & 0,83 & 0,50 \\
\hline
\end{tabular}

Sumber: Data riset yang diolah (2008 s.d. 2015)

Tabel 4 Uji Normalitas Rasio Keuangan Pemerintah Kab/Kota di Provinsi Kalimantan Timur

\begin{tabular}{lcccc}
\multicolumn{1}{c}{ Rasio } & $\begin{array}{c}\text { Sebelum Pemekaran } \\
\text { Kol. - }\end{array}$ & $\begin{array}{c}\text { Sig. } \\
\text { Smirnov }\end{array}$ & Kol. - Smirnov & $\begin{array}{c}\text { Sig. } \\
\text { (2-tailed) }\end{array}$ \\
& 0,57 & 0,91 & 0,38 & 1,00 \\
\hline Derajat Desentralisasi & 0,54 & 0,93 & 0,59 & 0,87 \\
Ketergantungan Keuangan Daerah & 0,57 & 0,91 & 0,48 & 0,98 \\
Kemandirian Keuangan Daerah & 0,44 & 0,99 & 0,73 & 0,66 \\
Efektivitas PAD & 0,27 & 1,00 & 0,41 & 1,00 \\
Efisiensi & 0,45 & 0,99 & 0,70 & 0,71 \\
Belanja Operasi/Total Belanja & 0,43 & 0,99 & 0,70 & 0,71 \\
Belanja Modal/Total Belanja & 0,88 & 0,42 & 0,00 & 0,00 \\
Belanja Tak Terduga/Total Belanja & 0,61 & 0,85 & 0,57 & 0,90 \\
Efisiensi Belanja Daerah & $2015)$ & & & \\
\hline
\end{tabular}

Sumber: Data riset yang diolah (2008 s.d. 2015) 
Tabel 3 menyajikan rasio APBD untuk Provinsi Kalimantan Timur, baik sebelum dan setelah pemekaran daerah. Data tersebut memiliki nilai asymp. sig. (2-tailed) lebih besar dari 0,05. Hal ini berarti data Pemerintah Provinsi Kalimantan Timur selama periode pengamatan merupakan data yang berdistribusi normal. Adapun untuk rasio keuangan APBD pemerintah kabupaten/kota yang berada di wilayah Kalimatantan Timur, hasil uji normalitas tersaji pada Tabel 4.

Tabel 4 menyajikan data rasio keuangan pemerintah kabupaten/kota di Provinsi Kalimantan Timur. Berdasarkan hasil perhitungan baik sebelum dan setelah pemekaran daerah, data tersebut memiliki nilai asymp. sig. (2-tailed) lebih besar dari 0,05. Hal ini berarti data seluruh pemerintah kabupaten/kota di Provinsi Kalimantan Timur selama periode pengamatan juga berdistribusi normal.

Langkah berikutnya yang ditempuh peneliti adalah melakukan uji beda dengan menggunakan t-test. Hasil dari uji beda untuk rasio keuangan Pemerintah Provinsi Kalimantan Timur tersaji pada Tabel 5.

Tabel 5 Uji Beda Rasio Keuangan Pemerintah Provinsi Kalimantan Timur

\begin{tabular}{lccc}
\hline \multicolumn{1}{c}{ Rasio } & Correlation & Sig. & Sig. (2-tailed) \\
\hline Derajat Desentralisasi & 0,398 & 0,602 & 0,028 \\
Ketergantungan Keuangan Daerah & 0,081 & 0,919 & 0,035 \\
Kemandirian Keuangan Daerah & 0,097 & 0,903 & 0,057 \\
Efektivitas PAD & $-0,488$ & 0,512 & 0,135 \\
Efisiensi & 0,444 & 0,556 & 0,374 \\
Belanja Operasi/Total Belanja & 0,418 & 0,582 & 0,354 \\
Belanja Modal/Total Belanja & 0,609 & 0,391 & 0,048 \\
Belanja Tak Terduga/Total Belanja & 0,891 & 0,109 & 0,039 \\
Efisiensi Belanja Daerah & 0,905 & 0,095 & 0,298 \\
\hline
\end{tabular}

Sumber: Data riset yang diolah (2008 s.d. 2015)

Teknik uji beda yang digunakan dalam riset ini adalah uji dua sampel berhubungan atau uji paired sample t test. Uji paired sample t test merupakan uji beda untuk dua sampel data berpasangan yang mengalami perlakuan berbeda. Penelitian ini membandingkan data pada Provinsi Kalimantan Timur dan kabupaten/kota yang ada di Provinsi Kalimantan Timur sebelum dan setelah pemekaran daerah.

Berdasarkan tabel 5 terlihat bahwa nilai sig. (2-tailed) untuk rasio derajat desentralisasi, rasio ketergantungan keuangan daerah, rasio belanja modal dan rasio belanja tidak terduga pada Pemerintah Provinsi Kalimantan Timur kurang dari 0,05. Hal ini berarti terdapat perbedaan secara signifikan antara nilai rasio-rasio tersebut sebelum pemekaran daerah dengan nilai setelah pemekaran daerah. Dengan kata lain, hasil penelitian ini dapat menolak Ho1 untuk kinerja APBD dalam perspektif derajat desentralisasi, tingkat ketergantungan daerah, rasio belanja modal dan rasio belanja tak terduga. Sedangkan untuk rasio kemandirian keuangan daerah, rasio efektivitas $\mathrm{PAD}$, rasio efisiensi, rasio belanja operasi dan rasio efisiensi belanja daerah pada Pemerintah Provinsi Kalimantan Timur memiliki nilai sig. (2tailed) lebih besar dari 0,05 . Hal ini berarti tidak terdapat perbedaan secara signifikan untuk nilai rasio-rasio tersebut baik sebelum maupun setelah pemekaran daerah, sekaligus tidak dapat menolak Ho1 untuk perspektif rasio-rasio dimaksud.

Pengujian yang sama dilakukan untuk data rasio keuangan seluruh kabupaten/kota di Provinsi Kalimantan Timur tersaji pada Tabel 6. 
Geliat Provinsi Kalimantan Timur Pasca Pemekaran Daerah

Diana Pujianty dan Puji Wibowo

Tabel 6 Uji Beda Rasio Keuangan Seluruh Pemerintah Kab/Kota di Provinsi Kalimantan Timur

\begin{tabular}{lccc}
\hline \multicolumn{1}{c}{ Rasio } & Correlation & Sig. & Sig. (2-tailed) \\
\hline Derajat Desentralisasi & 0,051 & 0,949 & 0,08 \\
Ketergantungan Keuangan Daerah & $-0,006$ & 0,994 & 0,133 \\
Kemandirian Keuangan Daerah & 0,032 & 0,968 & 0,094 \\
Efektivitas PAD & $-0,001$ & 0,999 & 0,681 \\
Efisiensi & $-0,077$ & 0,923 & 0,605 \\
Belanja Operasi/Total Belanja & $-0,099$ & 0,901 & 0,671 \\
Belanja Modal/Total Belanja & $-0,144$ & 0,856 & 0,556 \\
Belanja Tak Terduga/Total Belanja & 0 & 0 & 0,058 \\
Efisiensi Belanja Daerah & $-0,246$ & 0,754 & 0,134 \\
\hline
\end{tabular}

Sumber: Data riset yang diolah (2008 s.d. 2015)

Berdasarkan Tabel 6 terlihat bahwa nilai sig. (2-tailed) rasio derajat desentralisasi, rasio ketergantungan keuangan daerah, rasio kemandirian keuangan daerah, rasio efektivitas PAD, rasio efisiensi, rasio belanja operasi, rasio belanja modal, rasio belanja tidak terduga dan rasio efisiensi belanja pada seluruh pemerintah kabupaten/kota di Provinsi Kalimantan Timur lebih besar dari 0,05 . Hal ini berarti tidak terdapat perbedaan nilai rasio-rasio tersebut secara signifikan baik sebelum maupun setelah pemekaran daerah. Oleh karena itu, dalam penelitian ini, Ho2 sama sekali tidak dapat ditolak. Meskipun rasio kinerja APBD pemerintah kabupaten/kota di Provinsi Kalimantan Timur mengalami perubahan antara dua periode tersebut, namun perubahan tersebut tidak signifikan secara statistik.

Penulis menduga, berkurangnya jumlah pemerintahan kabupaten/kota kurang memacu kompetisi antardaerah dalam Provinsi Kalimantan Timur sehingga daerah lebih memilih berada dalam zona nyaman dengan mempertahankan status quo pengelolaan keuangan APBD. Hal ini sejalan pula dengan penelitian Mengkuningtyas (2008), Sucandrawati (2016), dan Nugroho (2016) bahwa pemekaran daerah relatif kurang memberikan efek performa APBD.

Provinsi Kalimantan Timur yang wilayahnya harus dimekarkan, memiliki motivasi yang tinggi untuk berkompetisi dengan 'saudara barunya' yaitu Kalimantan Utara. Hal ini terbukti dari perbedaan secara signifikan ke arah yang lebih baik atas beberapa rasio khususnya derajat desentralisasi dan ketergantungan keuangan daerah. Adapun rasio pengelolaan belanja khususnya belanja modal dan belanja tak terduga, meskipun berubah secara signifikan, namun perubahan tersebut tidak sepenuhnya ke arah yang lebih baik, khususnya untuk belanja modal yang justru mengalami penurunan.

Satu contoh yang menarik dari kinerja APBD Provinsi Kalimantan Timur adalah rasio derajat desentralisasi. Adanya perbedaan derajat desentralisasi ditunjukkan dengan meningkatnya rasio PAD terhadap total pendapatan daerah dalam APBD Kalimantan Timur. Sebelum era pemekaran daerah (2008 s.d. 2011), rasio PAD terhadap pendapataan daerah rata-rata sebesar 40 persen. Adapun rasio PAD sesudah pemekaran daerah (2012 s.d. 2015) rata-rata mencapai 52 persen. Hal ini antara lain mengindikasikan bahwa Provinsi Kalimantan Timur relatif berhasil mempertahankan capaian PAD melalui intensifikasi dan ekstensifikasi.

Provinsi Kalimantan Timur kehilangan potensi pendapatan, khususnya pajak dan retribusi dari wilayah kabupaten/kota yang berpindah atau bergabung ke dalam Provinsi Kalimantan Utara. Potensi menurunnya pendapatan tersebut nampaknya disikapi secara bijak oleh pemda setempat dengan melakukan upaya intensifikasi dan ekstensifikasi penerimaan daerah. Oleh karena itu, pemekaran daerah justru memberikan efek positif bagi Pemerintah Provinsi Kalimantan Timur untuk menggali sumber penerimaan daerah yang baru. Fenomena ini sejalan dengan fiscal mobility theory (Bahl dan Lin 1992), dimana desentralisasi fiskal 
memacu mobilitas warga untuk memilih pelayanan publik yang lebih baik. Tentu saja ini perlu direspon dengan kebijakan fiskal yang mumpuni di daerah agar dapat menjaring sumber-sumber PAD baik berupa pajak maupun retribusi daerah.

Derajat desentralisasi yang menguat secara otomatis mendorong tingkat ketergantungan keuangan daerah menjadi berkurang. Kinerja APBD yang ditunjukkan oleh perbandingan pendapatan transfer dengan total pendapatan daerah menunjukkan fakta yang menarik. Pada periode 2008 s.d. 2011, pendapatan transfer dalam APBD Provinsi Kalimantan Timur ratarata mencapai 60 persen. Setelah dilakukannya pemekaran daerah, sejak 2012 hingga 2015 rata-rata tingkat ketergantungan keuangan daerah turun jauh hingga pada level 46 persen. Kondisi ini antara lain disebabkan oleh berpindahnya dua daerah yang memiliki sumber daya alam pertambangan umum dan migas ke Provinsi Kalimantan Utara. Kedua daerah tersebut adalah Nunukan dan Tarakan. Nunukan terkenal dengan daerah penghasil mineral, produk hutan, dan perikanan. Ketiga jenis komoditi tersebut merupakan komponen pendapatan yang dibagihasilkan antara pusat dan daerah dalam bentuk dana bagi hasil. Sementara Kota Tarakan merupakan daerah yang kaya dengan sumber minyak dan gas bumi yang juga menjadi elemen penting dalam skema hubungan keuangan pusat dan daerah. Menurunnya tingkat ketergantungan keuangan daerah menunjukkan bahwa Provinsi Kalimantan Timur relatif lebih mandiri pada era setelah pemekaran daerah. Hal ini konsisten dengan pencapaian realisasi PAD yang secara rata-rata juga membaik sejak tahun 2012.

Realisasi belanja relatif tidak mengalami perubahan secara signifikan. Perbedaan signifikan justru diperlihatkan oleh rasio belanja modal terhadap total belanja APBD Provinsi Kalimantan Timur yang mengalami sedikit penurunan. Sebelum dimekarkan, rata-rata rasio belanja modal dalam periode pengamatan mencapai 26 persen. Namun, dalam empat tahun setelah pemekaran daerah, rasio belanja modal secara rata-rata hanya mencapai 22 persen. Menurunnya belanja modal tersebut mengindikasikan bahwa tidak terdapat peningkatan aktivitas pengadaan aktiva tetap, khususnya infrastruktur. Kondisi ini tentu saja sangat disayangkan mengingat realisasi PAD di satu sisi mengalami peningkatan namun belanja modal justru mengalami penurunan.

Masyarakat tentu akan menilai bahwa pungutan daerah yang selama ini disumbangkan kepada pemerintah daerah ternyata tidak dibarengi dengan peningkatan kualitas fasilitas publik. Bisa jadi di kemudian hari akan muncul suara-suara minor dari sebagian kalangan masyarakat yang menuntut perbaikan fasilitas publik seperti jalan dan jembatan. Tentu saja penulis menyadari bahwa perlu dilakukan pengamatan lebih dekat mengenai perubahan apa saja yang diperoleh masyarakat Kalimantan Timur pasca pemekaran daerah. Pengamatan secara lebih baik dibutuhkan untuk mengidentifikasi fasilitas publik mana saja yang masih memerlukan perbaikan. Dengan melihat ketimpangan data antara realisasi PAD yang meningkat di satu sisi namun pada saat bersamaan realisasi belanja modal justru menurun, memberikan potret yang kurang menggembirakan.

Rasio belanja yang mengalami perubahan secara signifikan berikutnya adalah belanja tak terduga. Rata-rata rasio belanja tak terduga selama periode pengamatan, mengalami kenaikan dari 15 persen menjadi 21 persen. Kenaikan ini antara lain disebabkan oleh meningkatnya belanja bagi hasil pajak ke kabupaten/kota dan wilayah pedesaan. Hal ini merupakan sebuah keniscayaan mengingat realisasi PAD selama periode pengamatan juga mengalami peningkatan. Dengan demikian, peningkatan PAD pada APBD Provinsi Kalimantan Timur pada akhirnya memberikan dampak positif kepada kabupaten/kota maupun desa dalam bentuk meningkatnya bagi hasil pajak.

Hal lain yang menarik dari potret kinerja APBD pasca pemekaran daerah adalah realisasi belanja operasi yang cenderung stagnan. Baik sebelum dan sesudah pemekaran daerah, selama periode pengamatan, rata-rata rasio belanja operasi masing-masing berkisar pada angka 58 persen dan 57 persen. Hal ini setidaknya memberikan penegasan bahwa meskipun 
rasio belanja modal menurun, Pemerintah Provinsi Kalimantan Timur tidak mengkompensasinya dengan kenaikan belanja operasi. Sebagaimana dimaklumi, salah satu komponen dalam belanja operasi adalah pengeluaran untuk gaji dan remunerasi aparatur daerah. Oleh karena itu, hal yang sedikit melegakan adalah Provinsi Kalimantan Timur tidak berupaya meningkatkan belanja operasinya meskipun mengalami penyusutan wilayah kerja.

\section{KESIMPULAN}

Penelitian ini membuktikan bahwa pemekaran daerah memberikan efek yang berbeda dalam hal kinerja APBD. Perbedaan kinerja APBD Pemerintah Provinsi Kalimantan Timur antara sebelum dan setelah pemekaran daerah ditunjukkan oleh indikator rasio derajat desentralisasi, rasio ketergantungan keuangan daerah, rasio belanja modal dan rasio belanja tidak terduga. Kondisi ini diduga karena keberhasilan Provinsi Kalimantan Timur untuk tetap menggali potensi daerahnya.

Kinerja APBD untuk seluruh kabupaten/kota yang ada di Provinsi Kalimantan Timur baik sebelum dan setelah pemekaran daerah relatif tidak berbeda untuk indikator rasio derajat desentralisasi, rasio ketergantungan keuangan daerah, rasio kemandirian keuangan daerah, rasio efektivitas $\mathrm{PAD}$, rasio efisiensi pendapatan, rasio belanja operasi, rasio belanja modal, rasio belanja tidak terduga dan rasio efisiensi belanja daerah. Kurangnya semangat berkompetisi diduga menyebabkan status quo pengelolaan APBD. Kompetisi atau persaingan antardaerah seyogianya terbangun untuk meningkatkan kesamaan pandangan antara apa yang diharapkan oleh masyarakat dengan suatu program yang dijalankan oleh pemerintahnya (Davoodi dan Zou 1998:244 dalam Wibowo 2008).

\section{REKOMENDASI}

Implikasi dari penelitian ini antara lain

a. Daerah didorong untuk meningkatkan PAD setelah pemekaran daerah agar tidak bergantung sepenuhnya pada dana transfer. Upaya peningkatan PAD tersebut dapat ditempuh melalui penggalian potensi pendapatan seperti objek sumber ekonomi daerah yang selama ini belum dikenakan pajak secara memadai.

b. Kebijakan pemekaran daerah perlu disertai dengan analisis biaya dan manfaat khususnya terkait aspek fiskal yang akan ditanggung oleh pemerintah pusat dan daerah.

c. Daerah diharapkan dapat merumuskan kebijakan smart spending yang lebih tepat sasaran sesuai kebutuhan masyarakatnya. Belanja modal merupakan salah satu contoh smart spending dimaksud. Belanja modal berupa pembangunan infrastruktur merupakan pengeluaran yang lebih memberikan efek multiplier bagi pembangunan daerah dibandingkan belanja daerah. Disamping itu, belanja untuk penyelenggaraan pendidikan dan kesehatan diharapkan terus meningkat untuk memberikan pemenuhan kebutuhan dasar masyarakat secara lebih baik.

d. Objek dalam penelitian ini adalah Pemerintah Provinsi Kalimantan Timur dan pemerintah kabupaten/kota di Provinsi Kalimantan Timur. Penelitian selanjutnya diharapkan dapat meneliti kinerja APBD Provinsi Kalimantan Utara dan pemerintah kabupaten/kota di Provinsi Kalimantan Utara yang merupakan daerah hasil pemekaran Provinsi Kalimantan Timur.

e. Penelitian kuantitatif deskriptif ini akan memberikan hasil yang lebih bermakna apabila dilengkapi dengan wawancara kepada pihak-pihak terkait baik para ahli di bidang keuangan daerah, maupun para pejabat di lingkungan Provinsi Kalimantan Timur. Disamping itu, riset ke depan diharapkan dapat memberikan komparasi kebijakan pemekaran daerah di negara lain, khususnya negara yang memiliki karakteristik seperti Indonesia. 


\section{DAFTAR PUSTAKA}

Azhar, Satya. (2008). Analisis Perbandingan Kinerja Keuangan Pemerintah Daerah Di Provinsi Lampung Sebelum Dan Setelah Pemekaran Wilayah. http://repository.usu.ac.id. (Diakses 16 Maret 2017).

Badan Pusat Statistik. (2017). Data APBD. Dari http://www.bps.go.id, diakses pada tanggal 1 Maret 2017.

Bahl, R.W. dan Linn, J. F., (1992). Urban Public Finance in Developing Countries, Oxford University Press, Oxford.

Direktorat Jenderal Perimbangan Keuangan. (2017). Data APBD. Dari http://www.djpk.depkeu.go.id, diakses pada tanggal 11 Februari 2017.

Endaryanto, Teguh, Muhammad Firdaus, Hermanto Siregar, dan Dedi Budiman Hakim. (2018). Analisis Kinerja Ekonomi dan Keuangan Daerah di Provinsi Lampung. Sosiohumaniora - Jurnal Ilmu-ilmu Sosial dan Humaniora, 20 (1):95-102.

Hamidi, Wahyu dan Tampubolon, Dahlan. (2017). Analisis Dampak Pemekaran Daerah Ditinjau dari Aspek Percepatan Pertumbuhan Ekonomi dan Peningkatan Kualitas Pelayanan Publik: Studi Pemekaran Kabupaten Kepulauan Meranti dari Kabupaten Bengkalis. JOM Fekon, 4 (1), 843-857.

Kementerian Dalam Negeri. (2006). Peraturan Menteri Dalam Negeri Nomor 13 Tahun 2006 tentang Pedoman Pengelolaan Keuangan Daerah.

Kementerian Dalam Negeri. (2017). Data APBD. Dari http://www.kemendagri.go.id, diakses pada tanggal 3 Maret 2017.

Mahmudi. (2015). Manajemen Kinerja Sektor Publik. Edisi Ketiga. Yogyakarta: Sekolah Tinggi Ilmu Manajemen YKPN.

Mahmudi. (2016). Analisis Laporan Keuangan Pemerintah Daerah. Edisi Ketiga. Yogyakarta: Sekolah Tinggi Ilmu Manajemen YKPN.

Mengkuningtyas, Yeni. (2008). Analisis Perbandingan Kinerja Keuangan Pemerintah Daerah Kota/Kabupaten Di Indonesia Sebelum Dan Setelah Pemekaran.Jurnal Ilmiah Mahasiswa FEB Universitas Brawijaya, 4 (1).

Mulatsih, Endang Sri. (2014). Analisis Kemampuan Keuangan Daerah Kabupaten/Kota di Provinsi Sumatera Selatan Sebelum dan Sesudah Pemekaran Daerah. Jurnal Ekonomi dan Informasi Akuntansi, 4 (1), 24-40.

Nugroho, Prayudi. (2016). Analisis Atas Kemandirian Pemda Dalam Mengelola Keuangannya. http://jurnal.pknstan.ac.id. (Diakses 15 Maret 2017)

Oates, W.E. (1972). Fiscal Federalism. New York: Harcourt Brace Jovanovich. 
Republik Indonesia. (2007). Peraturan Pemerintah Nomor 78 Tahun 2007 tentang Tata Cara Pembentukan, Penghapusan Dan Penggabungan Daerah. Lembaran Negara Republik Indonesia Tahun 2007 Nomor 162.

Republik Indonesia. (2010). Peraturan Pemerintah Nomor 71 Tahun 2010 tentang Standar Akuntansi Pemerintahan. Lembaran Negara Republik Indonesia Tahun 2010 Nomor 123.

Republik Indonesia. (2014). Penjelasan Atas Undang-undang Nomor 23 Tahun 2014 tentang Pemerintahan Daerah. Tambahan Lembaran Negara Republik Indonesia Nomor 5587

Santika, Raden Hady, Budi Santoso dan Hadi Mahmudi. (2018). Analisis Dampak Pemekaran Daerah Terhadap Kinerja dan Pemerataan Ekonomi di Kabupaten Lombok Utara. Jurnal Ilmu Pemerintahan: Kajian Ilmu Pemerintahan dan Politik Daerah, 3 (1), 16-23.

Sucandrawati, Ni Komang Ayu. (2016). Analisis Perbandingan Kinerja Keuangan Pemerintah Daerah di Provinsi Lampung Sebelum dan Setelah Pemekaran Wilayah. Tesis Program Magister Akuntansi Universitas Lampung.

Sugiyono. (2015). Statistika Untuk Penelitian. Bandung: Alfabeta.

Wibowo, Puji. (2008). Mencermati Dampak Desentralisasi Fiskal terhadap Pertumbuhan Ekonomi Daerah. Jurnal Keuangan Publik, 5(1),55-83. 